\title{
ОСОБЛИВОСТІ СПІЛКУВАННЯ ДІТЕЙ З ОСОБЛИВИМИ ПОТРЕБАМИ В ЗАКЛАДАХ СЕРЕДНЬОї ОСВІТИ
}

Наталія Воронська, Запорізький національний університет, ID ORCID 0001-9067-3118

Анотація. У статті проведено теоретичний аналіз основних напрямів взаємодії в загальноосвітній школі: учень-учень, учень-учитель, учень-батьки. Зазначено основні види спілкування, враховуючи віковий розвиток дитини. Описано специфріку спілкування дітей 3 особливими потребами за нозологіями: діти з порушеннями мовлення, зору, слуху, опорно-хового апарату, інтелектуального та психічного розвитку, аутична дитина. Також коротко окреслюється загальна специфіка кожної нозології за обраною класифрікацією. У результаті нами виділено деякі загальні риси таких дітей, а саме замкнутість, невпевненість у собі, зниження пізнавальної активності, порушення у розумінні емоцій та їх прояву. Стаття $є$ підгрунтям для подальших практичних досліджень у галузі інклюзивної освіти. Ключові слова: спілкування, діти з особливими потребами, загальноосвітні школи, інклюзивна освіта.

Наталия Воронская, Запорожский национальный университет Особенности общения детей с особенными потребностями в общеобразовательных школах аннотация. В статье проведен теоретический анализ основных направлений взаимодействия в общеобразовательной школе: ученик-ученик, ученик-учитель, ученик-родители. Указаны основные виды общения, учитывая возрастное развитие ребенка. Описана специфика общения детей с особыми потребностями согласно таким нозологиям: дети с нарушениями речи, зрения, слуха, опорно-двигательного аппарата, интеллектуального и психического развития, аутичный ребенок. Также кратко описывается общая специфика каждой нозологии по выбранной классификации. В результате нами выделены некоторые общие черты таких детей. А именно: замкнутость, неуверенность в себе, снижение познавательной активности, нарушения в понимании и проявлении эмоций. Статья является основой для дальнейших практических исследований в области инклюзивного образования.

Ключевые слова: общение, дети с особыми потребностями, общеобразовательные школы, инклюзивное образование.

Characteristics of children's communication with special needs in general education schools Annotation. The article presents a theoretical analysis of the main channels of communication in general education school: pupil-pupil, pupil-teacher, pupil-parents. The main types of communication are indicated, taking into account the age development of the child. The specificity of communication of children with special needs in nosology is described: children 
with speech disorders, visually impaired, hearing impaired, with disorders of the musculoskeletal system, intellectual development, mental development, autistic child. The general specificity of each nosology is also briefly determined by the selected classification. As a result, we have identified some common features of such children. Namely: isolation, lack of selfconfidence, decrease in cognitive activity, disturbances in the understanding of emotions and their manifestations. Using this analysis, it is possible to identify the factors that affect the level of formation of their communicative competence, in the future. The article is the basis for further practical research in the field of inclusive education.

Keywords: communication, children with special needs, general education schools, inclusive education.

Постановка проблеми. Інклюзія - розповсюджений нині термін, який увійшов у вітчизняний словниковий запас наприкінці XX ст. Цей термін уперше введено у Саламанкській декларації, яка була прийнята на конференції з питань освіти у червні 1994 року. Усі незалежні країни, зокрема й Україна, ратифікували цю декларацію.

Загальноосвітня школа покликана не тільки надавати знання учням, а й розвивати особистість дитини, виховувати, сприяти ï успішній соціалізації. В умовах інклюзивної освіти ця функція набуває ще більшого значення. Завдяки налагодженню дружніх стосунків в колективі зростає рівень толерантного ставлення до людей з особливостями, діти стають добрішими, більш чуйними, готовими допомогти.

Потреба у спілкуванні - одна з основних соціальних потреб. 3 віком ця потреба ускладнюється стає більш ширшою та усвідомленою. Коли дитина потрапляє у дитячій колектив, ï̈ індивідуальний розвиток стає тісно пов'язаним із колективом. Тому сприяння налагодженню ефективного спілкування, позитивної атмосфери у класі є важливим завданням педагогів, психологів та інших фахівців.

Якщо не надавати своєчасної корекційно-розвивальної підтримки, набуває стійкої форми соціальна дезадаптація, «...що виражається в неадекватності уявлень про себе, несформованості комунікативних навичок і умінь, нездатності відстоювати свою думку, налагоджувати взаємодію з соціальним оточенням, відсутності здатності самореалізуватися в різних сферах життедіяльності суспільства» [14].

Аналіз актуальних досліджень. Дослідженнями інклюзивної освіти в Україні та за кордоном займались такі вчені як: М. Астоянц, В. Байденко, Л. Будяк, В. Вольфенсбергер, В. Гудоніс, Е. Даніелс, М. Захарчук, Н. Клименюк, С. Клопота, А. Колупаєва, А. Коноплева, Р. Кролл, І. Кузава, 3. Ленив, Т. Лореман, Т. Лещинська, А. Мігалуш, Д. Мосис, Дж. Портер, Л. Савчук, Н. Софій, Г. Супруг, С. Уіенен, А. Хамініч, О. Чопік, М. Чайковський, І. Юхимець, Т. Ярая.

Особливості спілкування та взаємодії дітей з особливими потребами в своїх працях досліджували: О. Базилевська, Л. Батстра, Т. Богданова, В. Бондар, 
Ю. Бугера, Л. Василенко, Б. Волков, О. Денисова, Е. Зоутенхуфд, Н. Їлдіз, А. Коноплева, О. Коханова, Ги. Лефрансуа, Л. Макарчук, С. Миронова, О. Пасєка, Т. Поясок, М. Савчин, О. Сергєєнкова, С. Сисоєва, Т. Скрипник, О. Столярчук, А. Тіммерманс, З. Шевцов.

Мета статті здійснити аналіз психологічних особливостей спілкування дітей з особливими потребами в загальноосвітній школі.

Методи дослідження. У процесі написання статті нами активно використовувались такі загально-наукові методи як: аналіз, синтез, дедукція, індукція, системний аналіз.

Виклад основного матеріалу. Спілкування в школі має свою специфіку, тож розглянемо найбільш важливі напрями комунікативної взаємодії за якими здійснюється взаємодія: учень-учень, учень-учитель, учень - батьки.

Повноцінне спілкування за напрямом учень-учень, зазвичай, є більш важливим для дитини ніж успішність у школі чи стосунки з учителями, дорослими $[8,18]$. Як зазначають у своїх працях вітчизняні та зарубіжні вчені, більшість дітей з особливими потребами позбавлені повноцінного спілкування з оточуючими, не в усіх дітей є можливість навчатись інклюзивно та щодня спілкуватися 3 однолітками.

При позитивному сценарії розвитку стосунків молодшого учня з однолітками він переживає почуття довіри, альтруїзму, емпатії, які стають підгрунтям для здатності до емоційної децентрації. При негативному сценарії може бути відчуження, непорозуміння, конфлікти. У спілкуванні між підлітками в інклюзивному середовищі можуть виникати інтелектуальні бар'єри в наслідок різного інтелектуального розвитку підлітків.

У процесі спільної навчальної діяльності, задля становлення взаєморозуміння між учасниками спілкування, виникає потреба долання стереотипів сприймання, поведінки і врахування позицій партнерів, незалежно від нозології [13, 139].

Відповідно до досліджень В. Синьов, Г. Коберник, діти в школі однаково часто хотіли б змінити відносини і з однолітками, і зі співробітниками школи [10].

При розгляді взаємодії між учнем та вчителями важливо враховувати вік. Відповідно, для учнів початкової школи, особливо 1-2 класів, характерна велика сприйнятливість до кожного слова та дії вчителя. Як зазначає О. Сергєєнкова: «Старшокласники вже не сприймають учителя як втілення батька чи матері. У вчителеві юнаки хочуть бачити старшого друга, до якого можна звернутись за порадою щодо подальших життєвих планів» [3, 220].

Також важливим чинником, що може впливати на цей напрям взаємодії, є негативне сприймання учителем дитини з особливими потребами. Ці труднощі можуть виникати, коли у дитини є проблеми з поведінкою та вона може заважати навчанню інших дітей. Також зарубіжні дослідження вказують на зв'язок між негативним сприйманням учителів та гендерною структурою класу. У класах з більшою кількістю хлопців, учителі частіше повідомляють про випадки антисоціальної поведінки та проблеми 3 проявами емоцій [16; 17, 5].

Також має місце такий ефект сприймання, коли більш приваблива зовнішньо людина вважається більш розумною, доброю, успішною. Учителі більш прива- 
бливим дітям приписували більш високий інтелект, кращий статус у групі однолітків. Це може вкрай негативно впливати на розвиток особистості.

Взаємодія «учень-батьки» в контексті інклюзивного освітнього простору виконує найважливіші функції: виховання дітей у сім'ї, регуляція життя дитини, вибір навчального закладу, соціалізація у сім'ї, формування якостей особистості. Більшість дослідників підкреслюють, що від спілкування дітей та батьків залежить подальша взаємодія дітей із навколишнім середовищем. «Важко переоцінити роль сім'ї у процесі розвитку всіх сторін психіки дитини, починаючи від елементарних моторних навичок і закінчуючи становленням інтелекту, емоційної сфери, системи інтересів і цінностей, світогляду та особистості загалом» $[10,107]$. Також у результаті взаємодії дітей та батьків, відбувається особистісне зростання батьків та відносин між ними.

Батьки по відношенню до дитини з особливими освітніми потребами можуть відчувати різноманітні почуття: любов, роздратування, сором, почуття провини. Все залежить від характеру батьків, та кожної конкретної ситуації. Часто у батьків таких дітей є необхідність звертатись до психологів, педагогів.

У стосунках між підлітком та батьками важлива довіра, взаємоповага, що суттєво допомагає підлітку долати труднощі у спілкуванні з однолітками та поліпшити навчання. Як зазначають українські вчені О. Сергєєнкова, О. Столярчук, О. Коханова, О. Пасєка «Юнаки та дівчата потребують їх порад, підтримки, а здебільшого просто уваги до своїх особистісних проблем. Проте батькам часто бракує часу та бажання для відвертих розмов, а іноді вони створюють змістовний бар'єр у спілкуванні через свій скепсис, критику, безапеляційність і впевненість у непогрішності власного життєвого досвіду [3, 218].

Позитивна динаміка має місце у спілкуванні юнаків з дорослими. Досягнення поведінкової автономії юнаків приймається батьками, і це послаблює конфліктність їх стосунків.

М. Лісіна виокремлює такі види спілкування: ситуативно-особистісне спілкування, ситуативно-ділове спілкування, позаситуативно-пізнавальне спілкування, позаситуативно-особистісне спілкування [6].

Кожна нозологія накладає відбиток на модель спілкування дитини в шкільному колективі. Розглянемо детальніше ці особливості.

У нашому дослідженні ми використовуємо наступну класифікацію нозологій: порушення мовлення, зору, слуху, опорно рухового апарату, інтелектуального та психічного розвитку, аутична дитина [12].

Специфіка спілкування дітей з порушеннями мовлення залежить від виду мовного порушення. У дітей 3 алалією активніше розвиваються невербальна комунікація, вони краще розуміють мову, ніж користуються своїми мовними навичками (крім дітей із сенсорною алалією). Моторна алалія, дизартрія, ринолалія, заїкання супроводжуються низькою мовленнєвою активністю. Такі діти зі зниженим інтелектом часто більш говіркі, легко йдуть на контакт із людьми.

Дослідники В. Синьов, Г. Коберник зазначали «Те, що дитина з вираженими мовними порушеннями в багатьох випадках викликає до себе певне негативне ставлення однолітків ображає іiі самолюбство, змушує уникати колективних 
ігор». Такі діти часто переживають, бо мають труднощі у спілкуванні з однолітками [11].

Діти з порушеннями мовлення часто обирають позицію ізоляції, йдуть від контактів із здоровими людьми, стають замкнутішими. В учнівському змішаному колективі вони часто самостійно ізолюються або займають положення украй залежних. Та навпаки, дуже активне включення учня в різноманітні види діяльності, може розглядатись як прояв компенсаторних функцій психіки (Л. Волкова, М. Земцова, Л. Плаксіна, Л. Солнцева та ін.).

Цілковита втрата або глибокі порушення зору неодмінно позначаються на взаємодії дитини зі світом. Це накладає відбиток на спілкування. Найбільш уражена перцептивна сторона, оскільки сенсорні порушення найперше негативно впливають на соціальну перцепцію незрячої дитини - сприймання та оцінювання ситуації, співрозмовника, невербальних сигналів, тощо.

Порушення інтерактивної сторони спілкування проявляється в неправильній стратегії соціальної взаємодії, яка може проявлятись в упередженому відношенні до зрячих, страхах перед новими ситуаціями.

На думку дослідника В. Кобильченка найменше уражена комунікативна сторона спілкування, якщо порівнювати з інтерактивною та перцептивною сторонами спілкування. Таким дітям легше вдається обмін інформацією. Хоча «...спостерігаються труднощі використання невербальних знакових систем. Так зокрема, характерно, що з віком власна міміка незрячого «консервується», виразні можливості обличчя не реалізуються.» $[4,225]$.

Доречно зазначити, що на думку таких учених як В. Гудоніс, Є. Клопота, Г. Нікуліна, Є. Синьова, труднощі спілкування зрячих і незрячих полягають у негативних соціальних установках на взаємодію. А саме: неадекватний образ незрячого, недостатньо повно сформований образ партнера по спілкуванню у незрячого, бажання уникати спілкування, відсутність рівноправного відношення у спілкуванні [5].

Діти в загальноосвітній школі мають інший досвід спілкування та навчання. Коли дитина з порушеннями зору потрапляє у інклюзивний клас, це створює нову складну соціальну ситуацію, яка пов'язана із суперечностями між звичайними образами взаємодії з особами, які мають порушення зору, і новими умовами навчання в середовищі зрячих $[13,136]$.

Тож незрячі і слабкозорі діти мають низький рівень залучення в соціальні групи, недостатньо проявляють активність у спілкуванні з іншими дітьми, часто уникають близьких міжособистісних стосунків [14, 230].

Щодо проблем зі слухом, слух відіграє важливішу роль у вивченні та використанні мови. Щоб контролювати вимову звуків дитині необхідна допомога ззовні. Це призводить до зниження активності налагодження соціальних контактів, пізнання навколишнього світу, порушення словесно-логічного мислення.

Як відмічає В. Синьов, «система органів чуття, завдяки яким глухий учень відчуває зовнішній вплив - сукупну інформацію, змінена. Унаслідок цього середовище впливає на його психіку в зовсім інших співвідношеннях: деякі види впливу - майже в тому самому обсязі, що й у тих, хто чує, другі - у меншо- 
му, треті - як зовсім незначні». Отже, психіка дітей з проблемами слуху розвивається зовсім по іншому.

У свою чергу Г. Коберник додає, що такі діти та підлітки виявляють велике бажання добре вчитись, зчитувати інформацію з губ, що сприяє кращому розвитку особистості такої дитини, виховується бажання долати труднощі [11].

Діти з порушеннями слуху важко їдуть на контакт з однолітками, тому педагогам необхідно задіяти увагу дітей до однолітків. Для цього, як визначає О. Мельничук, використовуються різноманітні прості ігри парами, виконання доручень для двох, трьох дітей і т. ін.

Діти 3 порушеннями опорно-рухового апарату мають тенденцію ворожо сприймати оточуючих та ідеалізувати близьких людей. Що часто призводить до відмежування від соціального оточення та втрати навичок конструктивної взаємодії [2].

Як зазначають I. Мамайчук, С. Дуванова, Н. Трофімова та інші вчені, емоційні розлади дітей з ДЦП мають різні форми: емоційна збудливість, дратівливість, загальмованість, плаксивість, боязкість, коливання настрою, зниження критики, інертність емоційних реакцій. Причини цього криються у наявності фізичного дефекту, виховання по типу гіперопіки чи ранньої депривації [3].

При збереженому інтелекті часто спостерігається низький рівень самостійності, впевненості в собі, низька пізнавальна активність. Все це свідчить про дисгармонійний психічний розвиток дитини з ДЦП.

Проблема низької комунікативної активності особливо гостро постає у підлітковому віці. Т. Скрипник визначає два типи перешкод у розвитку дитини 3 особливими потребами. Перший тип - це певні фізичні, фізіологічні чи психічні розлади, другий - вторинні явища, такі як власна неповноцінність, відчуженість [2].

Якщо розглядати дітей із порушеннями інтелектуального розвитку, то в загалом їм притаманне наслідування мови дорослих, некритичність, відсутність стійких мотивів, неадекватна оцінка ситуацій. Інколи при порушеннях інтелектуального розвитку мають місце виражені психопатичні форми поведінки. Такі діти часто бувають грубі, недисципліновані, їм важко вдається відповідати морально-етичним нормам поведінки.

Чим доросліше стає дитина 3 інтелектуальними порушеннями, важчими стають стосунки з однолітками. Причиною є те, що колектив розподіляється на підгрупи. Дослідниця Л. Руденко акцентує увагу, що у розумово відсталих підлітків ставлення до якостей особистості менш диференційоване, ніж у дітей з нормальним інтелектуальним розвитком, через що вони дають одноліткам загальну оцінку: «добрий» або «поганий» [9, 199].

Стосовно помірного ступеня розумової відсталості, такі діти важче йдуть на контакт з однолітками. Ця особливість зростає у підлітковому віці. Діти молодшого шкільного віку найбільш чутливі до впливу однолітків. Підлітки навпаки рідко реагують на ініціативу від однолітків.

Ізольованість дитини може спричинити спонтанну агресію, та недовіру дитини до оточення та в подальшому до соціуму. Тому важливо активно залучати

«ОСОБЛИВА ДИТИНА: навчання і виховання», № 1, 2019 
таких дітей до життя колективу та навчання. Результати дослідження зарубіжних учених вказують на зв'язок кількості залучених до навчання дітей 3 інтелектуальними порушеннями та виникненням проблемної поведінки у класі. Чим більше залучених до навчання, тим нижче показник частоти виникнення проблемної поведінки [16, 181].

Такі вчені, як Т. Власова, Т. Ілляшенко, В. Лубовський, Н. Пипіна відзначають, що частіше затримка психічного розвитку характеризується низьким обсягом загальних знань, незрілістю мислення, низькою цілеспрямованістю, швидкою втомлюваністю при інтелектуальній діяльності, зацікавленістю в ігровій діяльності. Може спостерігатися домінування затримки розвитку емоційної сфери, або затримка інтелектуальної сфери.

Н. Бастун, О. Дмитриева, Т. Сак, В. Старцева стосовно цього зазначали, що емоційна сфера таких дітей ніби перебуває на більш ранньому ступені розвитку. Їм властива яскравість та жвавість емоцій, переважання емоційних реакцій у поведінці, ігрових інтересів, навіюваність та недостатня самостійність.

Деяким дітям подобається спокійні заняття (наприклад, малювання) але більшість віддає перевагу активним видам діяльності. Діти із затримкою психічного розвитку схильні до зривів, без достатніх на те підстав. Після цього вони можуть довго відчувати незручність. Вони часто образливі й запальні, грубі, у деяких ситуаціях проявляють жорстокість. Та в той же час такі діти дуже чутливі до звинувачень, особливо коли звинувачення несправедливі. Їм важко потім заспокоїтися. Фізично слабкіші учні легко підкоряються «авторитетам» i можуть підтримувати своїх «ватажків» навіть тоді, коли ті явно не мають рації.

Перейдемо до розгляду особливостей спілкування дітей з аутичними розладами. Н. Базима звертає увагу на незвичні індивідуальні засоби комунікації, поєднання вербальних форм (слова, вигуки, вокалізаціі) з невербальними формами (погляд, жести, спрямовані та неспрямовані рухи) [1].

Дослідники М. Лісіна, В. Лебединський, І. Логвинова, Т. Скрипник як одну 3 основних особливостей комунікації таких дітей виділяють аутокомунікацію. Це виявляється як ігнорування емоційного стану партнера по спілкуванню. Відсутність зовнішніх проявів емоцій на обличчі може сприйматись оточуючими як байдужість. Емоція страху може бути фоновою емоцією. Дитина справляється 3 цією емоцією специфічним чином: використання стереотипних рухів, використання аутостимуляції.

Як зазначає Г. Супрун, у дітей з аутизмом виникають труднощі у формуванні навичок спілкування, які важливі для соціального розвитку. «Діти з аутизмом на відміну від своїх однолітків, що розвиваються типово, не здатні до спонтанного формування таких навичок, які стають фундаментом соціального розвитку, - дивитися в очі, наслідувати рухи губ та міміку, віддзеркалювати емоційні реакції, емоційно співпереживати емоціям іншої людини». І. Логвінова засвідчує такі специфічні риси комунікації дітей з аутизмом: менша спрямованість до спілкування, нездатність проявляти комунікативну ініціативу, переважання нецілеспрямованих невербальних сигналів, зниження інтересу до партнера в процесі комунікації [7, 35]. 
Висновки та перспективи подальших наукових досліджень. Виходячи 3 вищевикладеного випливає, що особливості спілкування дітей з фізичними та психічними порушеннями в загальноосвітній школі можуть характеризуватись тикими негативними проявами, як замкнутість, невпевненість у собі, зниження пізнавальної активності, порушення у розумінні емоцій та їх прояву. Ці риси можуть стосуватись не тільки тих, хто має особливі потреби. Важливим завданням є створення атмосфери продуктивного, дружнього спілкування. Стає очевидною необхідність розвитку комунікативних навичок усіх дітей в інклюзивних класах загальноосвітніх шкіл. Розв'язанню проблеми може сприяти розроблення і впровадження спеціальних тренінгів комунікативної компетентності для інклюзивних класів.

Здійснивши теоретичний аналіз специфіки спілкування дітей з особливими освітніми потребами, у подальшому є можливість виділити чинники які впливають на рівень сформованості комунікативної компетентності.

Це дослідження може бути корисним для педагогів, психологів, соціальних педагогів, батьків дітей з особливими потребами та всіх тих, хто цікавиться питаннями інклюзивної освіти.

\section{ЛITEPATУPA}

1. Базима Н. В. Вивчення мовленнєвої активності дітей з аутистичними порушеннями старшого дошкільного віку / Н. В. Базима // Збірник наукових праць Кам'янець - Подільського національного університету імені Івана Огієнка / За ред. О. В. Гаврилова, В. І. Співака. - Серія: Соціально-педагогічна. Вип. 23. - 2013. - С. 22-30.

2. Бочелюк В. Й. Психологія людини з обмеженими можливостями. Навч. посіб. / В. Й. Бочелюк, А. В. Турубарова. - К.: Центр учбової літератури, 2011. - 264 с.

3. Вікова психологія: [навч. посіб.] / О. П. Сергєєнкова, О. А. Столярчук, О. П. Коханова, О. В. Пасєка. - К.: Центр учбової літератури, 2012. - 376 с.

4. Кобильченко В. В. Соціально-психологічні основи розвитку та корекції особистості підлітка в нормі і при патології зору: монографія / Кобильченко Вадим Володимирович. - К.: Освіта України, 2010. - 552 с.

5. Клопота 6 . А. Психологічні основи інтеграції в суспільство осіб з вадами зору: монографія / Клопота Євгеній Анатолійович. Запоріжжя: ЗНУ, 2014. - 408 с.

6. Лисина М. И., Галигузова Л. Н. Становление потребности детей в общении со взрослыми и сверстниками / М. И. Лисина, Л. Н. Галигузова // Исследования по проблемам возрастной и педагогической психологии / Под ред. Лисиной М. И. - М., 1980. - 387 с.

7. Логвінова І. П. До проблеми формування невербальних засобів комунікативної діяльності дітей з розладами спектра аутизму / І. П. Логвінова // Логопедія. - 2010. - № 2. - С. $40-44$.

8. Нагорна О. Б. Особливості корекційно-виховної роботи з дітьми з особливими освітніми потребами: навчально-методичний посібник / О. Б. Нагорна. - Рівне, 2012. - 99 с.

9. Руденко Л. М. Міжособистісні стосунки дітей з розумовою відсталістю як детермінанта агресивної поведінки / Л. М. Руденко // Наукові записки [Національного педагогічного університету ім. М. П. Драгоманова]. 2014. - Вип. 121. - С. 197-205. Режим доступу: http:// nbuv.gov.ua/UJRN/Nzped_2014_121_29

«ОСОБЛИВА ДИТИНА: навчання і виховання», № 1, 2019 
10. Семья в психологической консультации: [под. ред. А. А. Бодалева, В. В. Столина]. М.: Психология, 2009. - 144 с.

11. Синьов В. М. Основи дефектології: Навч. Посібник. / В. М. Синьов, Г. М. Коберник - К: Вища шк., 1994. -143 c.

12. Шевцов 3. М. Основи інклюзивної педагогіки [текст]: підручник / 3. М. Шевцов - К. : «Центр учбової літератури», 2016. - 248 с.

13. Gudonis, V. Klopota, Y. (2017). Features of Interpersonal Interaction of Blind and Visually Impaired Youth with Student Group. Pedagogika. 125 (2), 132-142: http://www.pedagogika.leu. lt/index.php/Pedagogika/issue/view/17/showToc

14. Klopota, Y. E Klopota, O. (2017). Peculiarities Of Interpersonal Cooperation Of Youth With Different Vision Level. New Educational Review, 48 (2), 227-236: http://www.educationalrev. us.edu.pl/e48/a18.pdf

15. Timmermans A. C., H. de Boer, M. P. C. van der Werf. (2016). An Investigation of the Relationship between Teachers' Expectations and Teachers' Perceptions of Student Attributes. Social Psychology of Education 19: 217. doi:10.1007/s11218-015-9326-6.

16. Wienen, A. W., Batstra, L., Thoutenhoofd, E., Bos, E. H., de Jonge, P. (2018) Do trouble some pupils impact teacher perception of the behaviour of their classmates? European Journal of Special Needs Education 16 January 2018, pp. 1-10.

17. Yildiz, N. G. (2015). Teacher and student behaviors in inclusive classrooms. Kuram ve Uygulamada Egitim Bilimleri. Volume 15, Issue 1, 2015, pp. 177-184.

\section{REFERENCES (TRANSLATED AND TRANSLITERATED)}

1. Bazyma N. V. (2013) Vyvchennya movlennyevoyi aktyvnosti ditey z autystychnymy porushennyamy starshoho doshkil'noho viku. Zbirnyk naukovykh prats' Kam'yanets' - Podil's'koho natsional'noho universytetu imeni Ivana Ohiyenka, 23, 22-30. [in Ukrainian].

2. Bocheliuk V.I) Turubarova A. V. (2011) Psykholohiia liudyny z obmezhenymy mozhlyvostiamy. Navch. posib. Kyiv, Tsentr uchbovoi literatury [in Ukrainian].

3. Serhyeyenkova O. P., Stolyarchuk O. A., Kokhanova O. P., Pasyeka O. V. (2012) Vikova psykholohiya. Kyiv: Tsentr uchbovoyi literatury [in Ukrainian].

4.Kobyl'chenko V.V.(2010) Sotsial'no-psykholohichni osnovy rozvytku ta korektsiyi osobystosti pidlitka v normi i pry patolohiyi zoru. Monograph. Kyiv: Osvita Ukrayiny [in Ukrainian].

5. Klopota Y. A. (2014) Psykholohichni osnovy intehratsiyi v suspil'stvo osib z vadamy zoru. Monograph. Zaporizhzhya: ZNU [in Ukrainian].

6. Lisina M. I., Galiguzova L. N. (1980) Stanovlenie potrebnosti detej v obshchenii so vzroslymi i sverstnikami. Issledovaniya po problemam vozrastnoj i pedagogicheskoj psihologii. Moskva. [in Russian].

7. Lohvinova I. P. (2010) Do problemy formuvannia neverbalnykh zasobiv komunikatyvnoi diialnosti ditei z rozladamy spektra autyzmu. Lohopediia. № 2, pp. 40-44 [in Ukrainian].

8. Nahorna O. B. (2012) Osoblyvosti korektsiino-vykhovnoi roboty z ditmy z osoblyvymy osvitnimy potrebamy. Rivne [in Ukrainian].

9. Rudenko L. M. (2014) Mizhosobystisni stosunky ditei z rozumovoiu vidstalistiu yak determinanta ahresyvnoi povedinky. Naukovi zapysky [Natsionalnoho pedahohichnoho universytetu im. M. P. Drahomanova]. 121. pp. 197-205 [in Ukrainian]. Retrieved from: http:// nbuv.gov.ua/UJRN/Nzped_2014_121_29 
10. Bodaleva A. A., Stolina V. V. (2009) Sem'ja v psihologicheskoj konsul'tacii. Moskva: Psihologija [in Russian].

11. Synov V. M. (1994) Osnovy defektolohii. Kyiv: Vyshcha shk [in Ukrainian].

12. Shertsov Z. M. (2016) Osnovy inkliuzyvnoi pedahohiky. Kyiv. «Tsentr uchbovoi literatury» [in Ukrainian].

13. Gudonis, V. Klopota, Y. (2017). Features of Interpersonal Interaction of Blind and Visually Impaired Youth with Student Group. Pedagogika. 125 (2), 132-142: http://www.pedagogika.leu. lt/index.php/Pedagogika/issue/view/17/showToc

14. Klopota, Y. E Klopota, O. (2017). Peculiarities Of Interpersonal Cooperation Of Youth With Different Vision Level. New Educational Review, 48 (2), 227-236: http://www.educationalrev. us.edu.pl/e48/a18.pdf

15. Timmermans A. C., H. de Boer, M. P. C. van der Werf. (2016). An Investigation of the Relationship between Teachers' Expectations and Teachers' Perceptions of Student Attributes. Social Psychology of Education 19: 217. doi:10.1007/s11218-015-9326-6 [in English].

16. Wienen A. W., Batstra L., Thoutenhoofd E., Bos E. H., de Jonge P. (2018) Do trouble some pupils impact teacher perception of the behaviour of their classmates? European Journal of Special Needs Education 16 January 2018, pp. 1-10 [in English].

17. Yildiz N. G. (2015). Teacher and student behaviors in inclusive classrooms. Kuram ve Uygulamada Egitim Bilimleri. Volume 15, Issue 1, 2015, pp. 177-184 [in English]. 